\title{
Assessment of Genetic Variability and Divergence in Finger Millet Accessions at Mid Hills of Uttarakhand
}

\author{
Laxmi Rawat $^{1 *}$, Shambhoo Prasad ${ }^{1}$, Tejpal Singh Bisht ${ }^{2}$, \\ Dinesh Chandra Naithani ${ }^{1}$ and J. Kumar ${ }^{3}$ \\ ${ }^{1}$ College of Forestry, Ranichauri, Tehri Garhwal, V.C.S.G. Uttarakhand University of \\ Horticulture and Forestry, Bharsar, India \\ ${ }^{2}$ KVK, Ranichauri, Tehri Garhwal. V.C.S.G. Uttarakhand University of Horticulture and \\ Forestry, Bharsar, India \\ ${ }^{3}$ College of Agriculture, G. B. Pant University of Agriculture \& Technology, Pantnagar, India \\ *Corresponding author
}

\section{A B S T R A C T}

Keywords

Finger millet,

Heritability, Divergence and variability

Article Info

Accepted:

22 October 2018

Available Online:

10 November 2018
The present experiment was carried out to assess the nature and magnitude of genetic variability and divergence among 200 finger millet accessions including four check varieties viz., PRM-1, PRM-2, VL-352 and GPU-28 and also to identify diverse parents for use in further breeding programmes. The seeds of each line were sown in augmented design and each line was represented by one row of 3 meters length and spaced $22.5 \mathrm{~cm}$ apart. Variability study indicated moderate phenotypic and genotypic coefficient of variation accompanied by high heritability and moderate genetic advance as per cent of mean for all the traits except number of productive tillers per plant. Mahalanobis $\mathrm{D}^{2}$ statistics grouped all the 200 accessions of finger millet into fifteen clusters. The accessions in cluster VI and XV exhibited higher degree of genetic diversity. The accessions in cluster $\mathrm{X}$ were found suitable for days to 50 per cent flowering, number of fingers per plant, plant height, days to maturity, seed yield and 1000-seed weight. Days to 50 per cent flowering and plant height contributed maximum with contribution rate of $48.33 \%$ and $21.79 \%$ respectively towards the genetic divergence. The accession IC476030 was identified as early maturing with higher seed yield per plant. Therefore, the identified accession can be used in the crossing programme for developing an ideal high yielding variety that can perform better under low temperature conditions at mid and high hills of Uttarakhand.

\section{Introduction}

Finger millet (Eleusine coracana (L.) Gaertn.) is an allotetraploid $(2 \mathrm{n}=4 \mathrm{X}=36)$ belonging to the family Poaceae and the genus Eleusine. It is an annual herbaceous cereal crop widely grown and consumed by poor people in Africa and Asia. Finger millet is majorly grown in the semi-arid tropics of Asia and Africa. As the increase in population and industrialization throughout the world reduced the availability of agricultural land, by the end of 2050, the world is expected to face a severe food demand as stated by Gupta et al., (2017). To 
overcome such a situation, there is an urgent need to increase the production of cereals like finger millet, which has to be increased up to $4.5 \mathrm{t} \mathrm{ha}^{-1}$ by 2025 as argued by Borlaug, (2002). In present scenario of climate change, the crop like finger millet is gaining remarkable importance due to its climate resilient nature and nutritive value. Finger millet will be an ideal crop for climate resilient agriculture due to its adaptation in semi-arid tropics which are characterized by unpredicted weather and erratic rainfall. Increasing the finger millet production will make this high nutritional food available for the poor people of developing nations and will help to attain nutritional security.

But the productivity of finger millet per unit area is low because of variety of factors viz., lack of high yielding varieties, good quality seeds, poor agronomical package and practices, biotic and abiotic stresses. Therefore, it is urgent need to develop an ideal variety which can perform better under changing environmental conditions and having high nutrient composition with multiply diseases resistant.

The information on genetic diversity and genetic relationships among genotypes is a prerequisite and paramount important for successful breeding programme. Kahrizi et al., (2010) stated that the developing varieties with desirable traits require a thorough knowledge about the existing genetic variability present among genetic materials because more genetic diverse parents, the greater chances of obtaining higher heterotic expression in $\mathrm{F}^{1}$ 's and broad spectrum of variability in segregating population as reported by Shekhawat et al., (2001). Precise information on the nature and degree of genetic diversity helps the plant breeder in choosing the diverse parents for purposeful hybridization. Jagadev et al., (1991) argued that the character contributing maximum to the divergence should be given greater emphasis for deciding the type of cluster for purpose of further selection and the choice of parents for crossing. In views of these facts, the present investigation was undertaken with the objective to assessment of genetic variability and divergence in finger millet accessions and characters contributing to genetic diversity among finger millet genotypes for further utilization in breeding programme.

\section{Materials and Methods}

The present experiment was conducted at Gaja Research Station (1600- $1700 \mathrm{~m}$ above msl), College of Forestry, Ranichauri, Tehri Garhwal, Uttarakhand during Kharif-2016, consisting of 196 accessions and 4 check varieties viz., PRM-1, PRM-2, VL-352 and GPU-28. The seeds of each line were sown in augmented design and each line was represented by one row of 3 meter length and spaced $22.5 \mathrm{~cm}$ apart. The recommended package of practices was followed to raise good and healthy crop. Five plants were selected randomly from each entry for recording data on ten morpho-metric traits $v i z$. , days to 50 per cent flowering, number of tillers per plant, peduncle length $(\mathrm{cm})$, number of finger per plant, finger length $(\mathrm{cm})$, plant height $(\mathrm{cm})$, ear length $(\mathrm{cm})$, days to maturity, seed yield per plant (g) and 1000-seed weight (g).

The phenotypic and genotypic coefficients of variability (PCV, GCV) were calculated by the formulae suggested by Burton (1952). Heritability, in a broad sense, was estimated by the method described by Lush (1940) and GA as percentage of mean according to Johnson et al., (1955). The genetic diversity was studied using the Mahalanobis $\mathrm{D}^{2}$ technique (Mahalanobis, 1936) and the genotypes were grouped into different clusters following Tocher's method (Rao, 1952). 


\section{Results and Discussion}

\section{Genetic variability}

Genetic variability plays an important role in crop improvement programme because greater genetic variability ensures better chances of producing desired genotypes. In present investigation, genetic variability was estimated for yield and its contributing traits among 200 finger millet accessions. The analysis of variance clearly indicated that there was sufficient variability present in the tested materials which could be utilized in further finger millet breeding programme. The maximum phenotypic and genotypic variance exhibited by days to 50 per cent flowering (178.53 and 175.76), days to maturity (93.58 and 93.06), plant height (64.19 and 64.10), number of fingers per plant (34.95 and 29.94) and peduncle length (18.21 and 17.57). The higher phenotypic variance than genotypic variance may be due to the non-genetic factor which played an important role in the manifestation of these traits. Raddy et al., (2013) also reported higher phenotypic variance than genotypic variance for yield and yield attributes of finger millet. Higher phenotypic and genotypic variance for number of fingers per plant and days to 50 per cent flowering was reported by Suryanarayana $e t$ al., (2014) in finger millet.

It is interesting to note that the differences between genotypic and phenotypic coefficient of variation were minimum implying least influence of environment and additive gene effects indicating genotypes can be improved based on genotypic values because genotypic coefficient of variance is considered to be more useful than phenotypic coefficient of variance for assessing variability, as it depends on the heritable portion of variability. The difference between PCV and GCV was very low for all the studied traits except number of productive tillers per plant, indicating that this character were slightly influenced by the environment. The highest genotypic coefficient of variance was observed for number of fingers per plant (15.91) than days to 50 per cent flowering (14.27), ear length (12.80), finger length (12.08), 1000-seed weight (10.83) and peduncle length (10.00) indicating the importance of these traits in evaluation and selection of genotypes (Table 1). However, number of productive tillers per plant exhibited lowest value (4.28) of genotypic coefficient of variance followed by days to maturity (6.54) and seed yield per plant (7.81), indicating a narrow range of variability for these characters and restricting the scope for selection. Lowest genotypic and phenotypic value for days to maturity was also reported by Wolie et al., (2013); Karad et al., (2013) and Ganapathy et al., (2011) in finger millet. Moderate to high genotypic coefficient of variance for yield and its contributing traits was reported by Kumari and Singh (2015) in finger millet and argued that coefficient of variance indicated the extent of variability present for traits does not indicate the heritable portion. This could be ascertained from the heritability estimates, which is broad sense include both additive and non-additive gene effects and in narrow sense include the portion of heritable variation which is due to additive component as stated by Lush (1949).

All the traits exhibited more than 80 per cent heritability except number of productive tillers per plant $(30 \%)$. Plant height and days to maturity had 99 per cent heritability than days to 50 per cent flowering and ear length (98\%), finger length (97\%), peduncle length and 1000 -seed weight $(96 \%)$ while number of fingers per plant and seed yield per plant exhibited 85 and 87 per cent heritability respectively. High heritability of these traits indicating that the variation observed was mainly under genetic control and selection for these characters is likely to be effective. 
Fig.1 Mahalnobis euclidean distance among 200 finger millet accessions

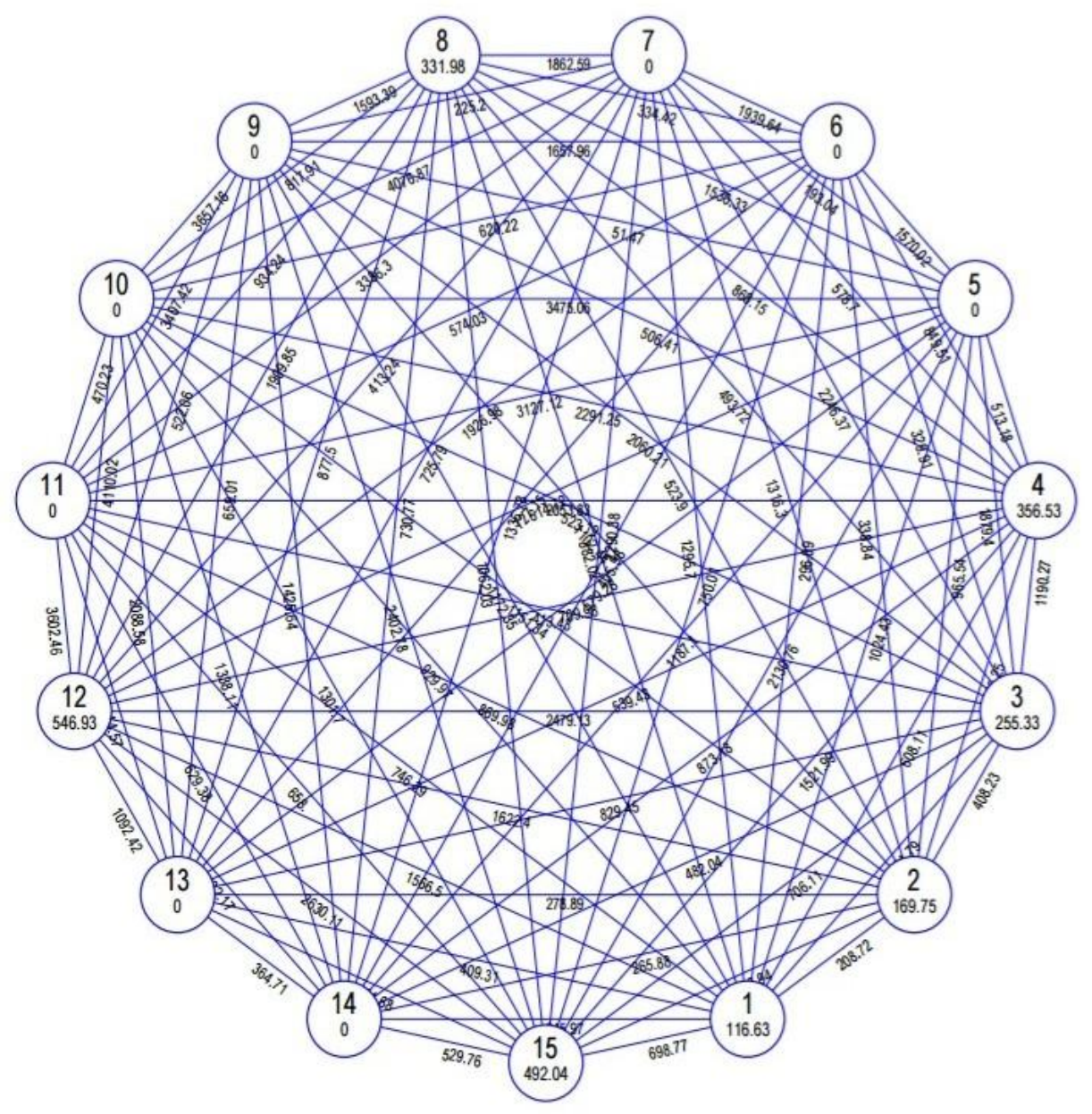

Table.1 Estimation of variability of yield and its attributing traits in finger millet

\begin{tabular}{|c|c|c|c|c|c|c|c|}
\hline S.N. & Characters & $\sigma_{g}^{2}$ & $\sigma_{\mathrm{g}}^{2}$ & GCV & PCV & $\begin{array}{l}\mathbf{h}^{2}(\text { Broad } \\
\text { sense) } \%\end{array}$ & $\begin{array}{l}\text { GA as \% } \\
\text { of mean }\end{array}$ \\
\hline 1 & Days to $50 \%$ flowering & 175.76 & 178.53 & 14.27 & 14.38 & 98 & 29.16 \\
\hline 2 & $\begin{array}{l}\text { Number of Productive } \\
\text { tillers per plant }\end{array}$ & 0.044 & 0.141 & 4.28 & 7.72 & 30 & 4.90 \\
\hline 3 & Peduncle length $(\mathrm{cm})$ & 17.57 & 18.21 & 10.00 & 10.80 & 96 & 20.23 \\
\hline 4 & No of fingers Per plant & 29.94 & 34.950 & 15.91 & 17.19 & 85 & 30.34 \\
\hline 5 & Finger length $(\mathrm{cm})$ & 13.34 & 13.65 & 12.08 & 12.22 & 97 & 24.61 \\
\hline 6 & Plant height $(\mathrm{cm})$ & 64.10 & 64.19 & 8.91 & 8.92 & 99 & 18.34 \\
\hline 7 & Ear length $(\mathrm{cm})$ & 2.14 & 2.17 & 12.80 & 12.90 & 98 & 26.20 \\
\hline 8 & Days to maturity & 93.06 & 93.58 & 6.54 & 6.56 & 99 & 13.44 \\
\hline 9 & Seed yield per plant $(\mathrm{g})$ & 0.018 & 0.020 & 7.81 & 8.33 & 87 & 15.10 \\
\hline 10 & 1000 Seed weight $(\mathrm{g})$ & 1.69 & 1.75 & 10.83 & 11.02 & 96 & 21.95 \\
\hline
\end{tabular}


Table. 2 Clustering pattern of 200 accessions of finger millet on the basis of genetic divergence

\begin{tabular}{|c|c|c|}
\hline Clusters & $\begin{array}{l}\text { Number of } \\
\text { accessions }\end{array}$ & Accessions \\
\hline $\mathbf{I}$ & 8 & IC- 0477399, IC- 0477777, IC- 477536, IC-476467, IC-476712, IC-477217, IC-476374, PRM-2@ \\
\hline II & 21 & $\begin{array}{l}\text { IC- 0477353, IC- 0476922, IC- 0477030, IC- 476039, IC-476808,IC-477378, IC-477381, IC-475836, IC-476495, } \\
\text { IC-476655, IC-477117,IC-476541, IC-476631, IC-476727, IC-476748, IC-477166, IC-477325, IC-477456, IC-476257, IC- } \\
476351\end{array}$ \\
\hline III & 16 & $\begin{array}{l}\text { IC-477484, IC-477599, IC-477649, IC-477657, IC-506471, IC-506475, IC-587964, IC-476687, IC-476858, IC-477095, IC- } \\
\text { 476923, IC-477067, IC-587982,IC-475933, IC-476560, IC-476567 }\end{array}$ \\
\hline IV & 17 & $\begin{array}{l}\text { IC- 0477237, IC-476568, IC-476959, IC-477113, IC-477156, IC-477316, IC-587978, IC-476680, IC-476711, IC-476745, } \\
\text { IC-476786, IC-476866, IC-477066, IC-476452, IC-476597, IC 476722 }\end{array}$ \\
\hline $\mathbf{V}$ & 7 & IC-476980, IC-477147, IC-476299, IC-476780, IC-476803, IC-476652, IC-476752 \\
\hline VI & 9 & IC-477802, IC-476731, IC-476737, IC-476814, IC-476816, IC-476846, IC-477216, IC-477223, IC-587981 \\
\hline VII & 18 & $\begin{array}{l}\text { IC- 0477155, IC- 0477157, IC-477426, IC-477467, IC-477025, IC-477096, IC-477161, IC-477246, IC-477299, IC-477373, } \\
\text { IC-587979, IC-587980, IC-476783, IC-476862, IC-587985, IC-587987, IC-587992, IC-476485 }\end{array}$ \\
\hline VIII & 17 & $\begin{array}{l}\text { IC-477556, IC-477620, IC-477632, IC-477045, IC-477103, IC-477198, IC-477210, IC-477210, IC-0477789, IC-0477249, } \\
\text { IC-476755, IC-476756, IC-476763, IC-587983, IC-587989, IC-476685 }\end{array}$ \\
\hline IX & 8 & IC-476921, IC-477135, IC-476412, IC-476462, IC-476772, IC-476795, IC-476986, VL- 352@ \\
\hline $\mathbf{X}$ & 11 & $\begin{array}{l}\text { IC- 0476988, IC-477385, IC-476870, IC-477382, IC-477177, IC-477395, IC-476030, IC-476196, IC-476373, IC-476471, } \\
\text { PRM-1C }\end{array}$ \\
\hline $\mathbf{X I}$ & 9 & IC-476932, IC-477402, IC-477415, IC-476389, IC-476523, IC-476663, IC-476804, IC-476810, IC-477323 \\
\hline XII & 19 & $\begin{array}{l}\text { IC- 0478273, IC- 0477766, IC- 0476636, IC- 0476893, IC-476883, IC-476916, IC-476958, IC-477431, IC-0476604, IC- } \\
\text { 476409, IC-476537, IC-476740, IC-476830, IC-476871, IC-476945, IC-477024, IC-477077, IC-476296, GPU- 28@ }\end{array}$ \\
\hline XIII & 15 & $\begin{array}{l}\text { IC- 0477361, IC- 477537, IC- 477045, IC-476779, IC- 477246, IC-477469, IC-477536, IC-477537, IC-477556, IC-587965, } \\
\text { IC-476868,IC-476707, IC-476901, IC-477052, IC-476520 }\end{array}$ \\
\hline XIV & 17 & $\begin{array}{l}\text { IC- 0477187, IC- 476248, IC- 476378, IC-476669, IC-476937, IC-477394, IC-587975, IC-476404, IC-476460, IC-476546, } \\
\text { IC-476753,IC-477160, IC-477302, IC-477314, IC-477317, IC-476388, IC-476395 }\end{array}$ \\
\hline$\overline{\mathbf{V}}$ & 8 & IC-587970,IC-476568,IC-476645,IC-477274,IC-476689,IC-476706,IC-476580,IC-476586 \\
\hline
\end{tabular}




\section{Int.J.Curr.Microbiol.App.Sci (2018) 7(11): 2912-2922}

Table.3 Intra and inter cluster distance $\left(\sqrt{ } \mathrm{D}^{2}\right)$ among 200 accessions of finger millet

\begin{tabular}{|c|c|c|c|c|c|c|c|c|c|c|c|c|c|c|c|}
\hline Cluster & I & II & III & IV & $\mathbf{V}$ & VI & VII & VIII & IX & $\mathbf{X}$ & XI & XII & XIII & XIV & $\mathbf{X V}$ \\
\hline $\mathbf{I}$ & 0.018 & 0.059 & 0.08 & 0.227 & 0.712 & 1.487 & 0.579 & 0.202 & 1.831 & 1.208 & 2.708 & 3.791 & 5.404 & 7.558 & 9.388 \\
\hline II & & 0.021 & 0.219 & 0.451 & 1.087 & 2.018 & 0.321 & 0.073 & 1.33 & 0.812 & 2.089 & 3.050 & 4.511 & 6.493 & 8.196 \\
\hline III & & & 0.027 & 0.07 & 0.383 & 0.969 & 0.997 & 0.465 & 2.537 & 1.791 & 3.552 & 4.782 & 6.574 & 8.934 & 10.915 \\
\hline IV & & & & 0.014 & 0.17 & 0.588 & 1.469 & 0.796 & 3.268 & 2.409 & 4.410 & 5.773 & 7.727 & 10.271 & 12.392 \\
\hline $\mathbf{V}$ & & & & & 0.055 & 0.186 & 2.504 & 1.598 & 4.748 & 3.698 & 6.106 & 7.691 & 9.920 & 12.78 & 15.129 \\
\hline VI & & & & & & 0.029 & 3.854 & 2.698 & 6.562 & 5.312 & 8.145 & 9.967 & 12.485 & 15.678 & 18.273 \\
\hline VII & & & & & & & 0.032 & 0.131 & 0.387 & 0.15 & 0.828 & 1.459 & 2.513 & 4.030 & 5.390 \\
\hline VIII & & & & & & & & 0.026 & 0.873 & 0.469 & 1.500 & 2.327 & 3.622 & 5.413 & 6.976 \\
\hline IX & & & & & & & & & 0.017 & 0.091 & 0.107 & 0.373 & 0.973 & 1.974 & 2.958 \\
\hline $\mathbf{X}$ & & & & & & & & & & 0.033 & 0.333 & 0.756 & 1.551 & 2.774 & 3.920 \\
\hline $\mathbf{X I}$ & & & & & & & & & & & 0.028 & 0.115 & 0.499 & 1.25 & 2.049 \\
\hline XII & & & & & & & & & & & & 0.021 & 0.174 & 0.665 & 1.272 \\
\hline XIII & & & & & & & & & & & & & 0.049 & 0.216 & 0.588 \\
\hline XIV & & & & & & & & & & & & & & 0.021 & 0.121 \\
\hline $\mathbf{X V}$ & & & & & & & & & & & & & & & 0.030 \\
\hline
\end{tabular}


Int.J.Curr.Microbiol.App.Sci (2018) 7(11): 2912-2922

Table.4 Cluster mean and contribution rate of yield and its attributes in finger millet

\begin{tabular}{|c|c|c|c|c|c|c|c|c|c|c|}
\hline Cluster & $\begin{array}{l}\text { Days to } \\
50 \% \\
\text { Flowering }\end{array}$ & $\begin{array}{c}\text { No. of } \\
\text { productive } \\
\text { tillers }^{-1} \\
\text { plant }^{-1}\end{array}$ & $\begin{array}{c}\text { Peduncle } \\
\text { Length }(\mathrm{cm})\end{array}$ & $\begin{array}{l}\text { No of } \\
\text { fingers } \\
\text { Plant }^{-1}\end{array}$ & $\begin{array}{l}\text { Finger } \\
\text { Length } \\
\text { (cm) }\end{array}$ & $\begin{array}{l}\text { Plant } \\
\text { Height } \\
\text { (cm) }\end{array}$ & $\begin{array}{c}\text { Ear } \\
\text { Length } \\
\text { (cm) }\end{array}$ & $\begin{array}{l}\text { Days to } \\
\text { Maturity }\end{array}$ & $\begin{array}{l}\text { Seed } \\
\text { Yield } \\
\text { plant }^{-1} \\
\text { (g) }\end{array}$ & $\begin{array}{l}1000 \text { Seed } \\
\text { Weight (g) }\end{array}$ \\
\hline $\mathbf{I}$ & 86.326 & 4.727 & 39.510 & 34.571 & 12.777 & 88.743 & 11.756 & 142.867 & 11.603 & 1.692 \\
\hline II & 87.164 & 4.760 & 40.411 & 26.920 & 17.273 & 88.680 & 11.987 & 141.815 & 11.484 & 1.668 \\
\hline III & 77.726 & 4.824 & 41.212 & 35.993 & 16.142 & 88.984 & 11.036 & 136.478 & 12.019 & 1.728 \\
\hline IV & 101.502 & 4.881 & 41.738 & 35.047 & 15.801 & 91.580 & 11.507 & 154.278 & 12.015 & 1.684 \\
\hline $\mathbf{V}$ & 109.912 & 4.700 & 36.300 & 21.938 & 8.475 & 91.027 & 10.254 & 157.288 & 11.127 & 1.837 \\
\hline VI & 81.762 & 5.150 & 52.275 & 34.438 & 18.200 & 93.933 & 12.161 & 141.837 & 11.309 & 1.520 \\
\hline VII & 116.113 & 4.750 & 37.225 & 29.188 & 14.675 & 81.998 & 11.099 & 159.188 & 13.374 & 1.612 \\
\hline VIII & 85.017 & 4.948 & 43.929 & 39.176 & 19.846 & 96.073 & 11.595 & 141.726 & 12.403 & 1.704 \\
\hline $\mathbf{I X}$ & 112.563 & 5.350 & 36.075 & 23.438 & 15.300 & 94.993 & 9.431 & 158.637 & 11.589 & 1.880 \\
\hline $\bar{X}$ & 66.012 & 5.200 & 46.200 & 43.438 & 17.650 & 98.736 & 11.816 & 127.688 & 14.469 & 1.910 \\
\hline $\mathbf{X I}$ & 68.213 & 5.400 & 47.600 & 39.438 & 21.650 & 79.236 & 9.216 & 131.087 & 9.589 & 1.830 \\
\hline XII & 115.344 & 5.034 & 43.156 & 34.426 & 19.740 & 88.341 & 11.511 & 162.347 & 12.050 & 1.686 \\
\hline XIII & 94.813 & 4.200 & 36.300 & 23.438 & 20.750 & 83.011 & 12.646 & 148.688 & 12.129 & 1.630 \\
\hline $\mathbf{X I V}$ & 88.412 & 4.400 & 47.300 & 27.438 & 19.750 & 77.836 & 9.716 & 138.688 & 10.599 & 1.610 \\
\hline $\mathbf{X V}$ & 78.813 & 4.989 & 45.678 & 33.104 & 20.119 & 77.025 & 11.336 & 140.010 & 11.524 & 1.754 \\
\hline Contribution rate ( $\%)$ & 48.33 & 0.01 & 4.27 & 12.33 & 2.74 & 21.79 & 0.04 & 10.35 & 0.15 & 0.01 \\
\hline
\end{tabular}


Table.5 Diverse finger millet accessions based on genetic distance for traits under investigation

\begin{tabular}{|c|l|c|l|}
\hline SI. No. & Traits & Cluster & Suitable parents in cluster \\
\hline $\mathbf{1}$ & Days to $50 \%$ flowering & $\mathbf{X}$ & IC-476030 \\
\hline $\mathbf{2}$ & Number of Productive tillers per plant & $\mathbf{X I}$ & IC-477415 \\
\hline $\mathbf{3}$ & Peduncle length $(\mathrm{cm})$ & $\mathbf{V I}$ & IC-476814 \\
\hline $\mathbf{4}$ & No of fingers Per plant & $\mathbf{X}$ & IC-477385, IC-0476988 \\
\hline $\mathbf{5}$ & Finger length $(\mathrm{cm})$ & $\mathbf{X I I I}$ & IC-477558 \\
\hline $\mathbf{6}$ & Plant height $(\mathrm{cm})$ & $\mathbf{X}$ & IC-476030 \\
\hline 7 & Ear length $(\mathrm{cm})$ & $\mathbf{X I I I}$ & IC-476868 \\
\hline $\mathbf{8}$ & Days to maturity & $\mathbf{X}$ & IC-476030 \\
\hline $\mathbf{9}$ & Seed yield per plant $(\mathrm{g})$ & $\mathbf{X}$ & IC-476030 \\
\hline $\mathbf{1 0}$ & 1000 Seed weight $(\mathrm{g})$ & & \\
\hline
\end{tabular}

Similar results was also reported by Reddy et al., (2013); Ulaganathan et al., (2013) and Wolie et al., (2013) and stated that the traits had higher value of heritability can be used as a selection criteria for yield improvement in finger millet. Heritability estimates, along with GA as percentage of mean, are more important for improvement rather than heritability alone as argued by Johnson et al., (1955). Higher values for genetic advance was observed for number of fingers per plant (30.34) than days to 50 per cent flowering (29.16), ear length (26.20), finger length (24.61) and 1000-seed weight (21.95) while lower values for genetic advance was calculated for number of productive tillers (4.90) than days to maturity (13.44). Kumari and Singh (2015) also reported similar results in finger millet and stated that the high heritability associated with high genetic advance indicated, the variation was mostly due to additive gene effects, if these characters are subjected to any selection scheme for exploiting fixable genetic variance, a wide adopted genotype can be developed.

\section{Genetic divergence}

Mahalanobis $\mathrm{D}^{2}$ statistics technique, which is based on multivariate analysis of quantitative traits, is a powerful tool for measuring genetic divergence that serves as index for selection of parents with diverse origin while clustering of genotypes following the Tocher's method as described by Rao (1952). The 200 finger millet accessions grouped into fifteen clusters based on $\mathrm{D}^{2}$ values and the cluster's strength varied from eight accessions to twenty one accessions (Table 2). The clusters II had highest number of (21) accessions, followed by cluster XII (19), cluster VII (18), cluster IV, VIII and XIV (17), cluster III (16), cluster XIII (15) cluster X (11), cluster VI and XI (9) cluster I and XIII (8) and Cluster V had 7 accessions, which indicating the presence of high degree genetic diversity in the studied material and serve as good source of gene for economically important traits and can be selected for hybridization programme aimed as isolating desirable segregates for developing high yielding varieties of finger millet. Kumari and Singh (2015) also reported six grouped of finger millet genotypes based on $\mathrm{D}^{2}$ values and argued that there was no formal relationship between geographical diversity and genetic diversity, while Patel and Patel, (2012) stated that the genetic drift and selection in different environment could cause greater diversity than geographical distance. Therefore, the selection of parental materials for crossing programme simply 
based on geographical diversity may not be rewarding exercise. The choice of suitable diverse parents based on genetic divergence analysis would be more fruitful than the choice made on the basis of geographical distances.

The cluster $\mathrm{V}$ had maximum intra cluster distance (0.055) indicated that accessions fall in this cluster were relatively more diverse than the accessions fall within cluster XIII (0.049), cluster X (0.033),cluster VII(0.032), cluster XV (0.030) cluster VI (0.029), cluster XI (0.028) cluster III (0.027) cluster VIII (0.026), clusters II,XII,XIV (0.021), cluster I (0.018), cluster IX (0.017) and cluster IV (0.014) (Table 3 and Fig. 1). However, maximum inter-cluster genetic distance was observed between cluster VI and XV (18.273) followed by cluster VI and XIV (15.678), cluster V and XV (15.129), cluster V and XIV (12.78) and cluster IV and XV (12.392). The clusters with higher inter-cluster distances indicated that the genotypes included in those clusters had high genetic variation and hybridization between genotypes of these cluster may result heterotic hybrids because of convergence of diverse genes scattered in parents to progeny. The clusters with lowest inter-cluster distances indicated that genotypes present in these cluster pairs, genetically close to each other. The crosses between genotypes belonging to clusters separated by low inter cluster distance were likely to throw promising recombinants in the segregating generations. Wolie et al., (2013) also suggested that genotypes of most diverse cluster may be used as parents in hybridization programmes to develop high yielding varieties, while selection and choice of parents mainly depends upon contribution of characters towards divergence as stated by and Dinesh et al., (2010).

Different clusters showed superiority for different traits therefore, information on the contribution of these traits toward the genetic diversity is also essential for selecting the parents for hybridization programmes. Among the traits, days to 50 per cent flowering contributing maximum (48.33\%) towards total genetic divergence followed by plant height (21.79), number of finger plant per plant (12.33), days to maturity (10.35) suggesting scope for improvement in these characters while peduncle length $(4.72 \%)$ and finger length (2.74) exhibited low contribution towards total genetic divergence. However, less than one per cent variation was contributed by four important traits viz., number of productive tillers plant per plant, ear length, 1000-seed weight and seed yield plant per plant. Maximum contribution toward total genetic divergence by days to 50 per cent flowering and day to maturity was also reported by Kumari and Singh (2015) in finger millet. Cluster group means for 10 characters are presented in Table 4. Cluster X consisting 11 accessions showed higher cluster mean for number of finger per plant, plant height, seed yield per plant and 1000seed weight while lowest mean for days to 50 per cent flowering and days to maturity. Cluster XIII having 15 accessions, exhibited maximum cluster mean for finger length and ear length whereas, 9 accessions fall in the cluster VI and XI showed highest cluster means for peduncle length and number of productive tillers per plant respectively. It is observed that the cluster $\mathrm{X}$ had maximum cluster means for most of desirable characters viz., days to 50 per cent flowering, number of finger per plants, plant height, days to maturity, seed yield per plant and 1000-seed weight (Table 5). Therefore, genotypes fall in this cluster can be used for improvement of seed yield and yield contributing characters, simultaneously.

Thus, it can be concluded that selection of genotypes from the most divergent clusters may exhibit a high heterosis besides grain 
yield. Therefore, hybridization between the genetically diverse parents in further breeding programmes may produce large variability and better recombinants in the segregating generations.

\section{References}

Borlaug, N. E. (2002). Feeding a world of 10 billion people: the miracle ahead. In Vitro Cell. Dev. Biol. Plant 38, 221228.

Burton G W. (1952). Quantitative inheritance in grasses. Proceedings of the 6th International Grassland Congress, Pennsylvania, 1: 277-283.

Dinesh, K., Vikrant, T., Ramesh, B. B. and Sukram, P. (2010). Genetic diversity in finger millet (Eleusine coracana L.). Crop Improv. 37(1): 25-28.

Ganapathy, S., Nirmalakumari, A. and Muthiah, A. R. (2011). Genetic Variability and inter-relationship analysis for economic traits in finger millet germplasm. World J. Agri. Sci. 7(2): 185-188.

Gupta, S. M., Arora, S., Mirza, N., Pande, A., Lata, C., Puranik, S. (2017). Finger Millet: a "certain" crop for an "uncertain" future and a solution to food insecurity and hidden hunger under stressful environments. Front. Plant Sci. 8:643-657.

Jagadev, P. N., Shamal, K. M. and Lenka, L. (1991). Genetic divergence in rape mustard. Indian J. Genet. Plant Breed. 51: 465-466.

Johnson, H. W., Robinson, H. F., and Comstock, R. E. (1955). Estimates of genetic and environment variability in soyabean. Agron. J. 47: 314-318.

Kahrizi, D., Maniee, M., Mohammadi, R. and Cheghamirza, K. (2010). Estimation of genetic parameters related to morphoagronomic Traits of durum wheat
(Triticum turgidum var. durum). Biharean Biologist. 4(2): 93-97.

Karad, S. R., Patil, J. V. and Kale, A. A. (2013). Study of genetic diversity in finger millet (Elesuine coracana L.) genotypes using RAPD markers. Int. J. Integ. Sci. Innov.Technol. 2(4): 31-36.

Kumari S. and Singh S. K. (2015). Assesment of genetic diversity in promising finger millet [Eleusine coracana (L.) Gaertn] genotypes. The Bioscan 10(2): 825-830.

Lush J. L. (1940). Intra-sire correlation and regression of offspring on dams as a method of estimating heritability of characters. Proceedings of American Society of Animal Production, 33: 293301.

Lush, J. L. (1949). Heritability of quantitative characters in farm animals. Proceedings of 8th Congress of Genetics and Heriditas. 35: 356-375.

Mahalanobis P C. (1936). On the generalized distance in statistics. Proceedings of National Academy of Science India, 2: 9-55.

Patel, J. N. and Patel, N. K. (2012). Genetic diversity in Vigna radiata (L.) Wilczek. Life Sci. Leaflets. 11: 53-56.

Rao C. R. (1952). Advanced Statistical Methods in Biometric Research. New York: John Wiley \& Sons.

Reddy, C. V. C. M., Reddy, P. V. R. M., Munirathnam, P. and Gowda, J. (2013). Studies of genetic variability in yield and yield attributing traits of finger millet [Eleusine Coracana (L.) Gaertn]. Indian J. Agri. Res. 47(6): 549-552.

Shekhawat, U. S., Vijay, P. and Singhania, D. L. (2001). Genetic divergence in barley (Hordeum vulgare L.). Indian J. Agric. Res. 35(2): 121-123.

Suryanarayana, L., Sekhar, D. and Rao, N. V. (2014). Genetic variability and divergence studies in finger millet (Eleusine coracana (L.) Gaertn.). 
Current Microbial App. Sci. 3(4): 931- Wolie, A., Belete, K. and Dessalegn, T. 936.

Ulaganathan, V. and Nirmalakumari, A. (2013). Phenotypic selection of elite genotypes based on genetic analysis in finger millet [Eleusine coracana (L.) Gaertn] germplasm. Pl. Archives. 13(2): 1003-1008. (2013). Heritability, variance components and genetic advance of some yield and yield related traits in Ethiopian collections of finger millet (Eleusine coracana (L.) Gaertn.) genotypes. Afri. J. Biotechnol. 12(36): 5529-5534

\section{How to cite this article:}

Laxmi Rawat, Shambhoo Prasad, Tejpal Singh Bisht, Dinesh Chandra Naithani and Kumar, J. 2018. Assessment of Genetic Variability and Divergence in Finger Millet Accessions at Mid Hills of Uttarakhand. Int.J.Curr.Microbiol.App.Sci. 7(11): 2912-2922. doi: https://doi.org/10.20546/ijcmas.2018.711.333 